Notes and Comments

\title{
Additional breeding biology information on the Fuscous Flycatcher, Cnemotriccus fuscatus (Wied, 1831)
}

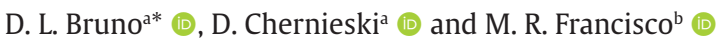 \\ aUniversidade Federal de São Carlos - UFSCar, Programa de Pós-graduação em Ecologia e Recursos Naturais, São Carlos, SP, Brasil \\ bUniversidade Federal de São Carlos - UFSCar, Departamento de Ciências Ambientais, Sorocaba, SP, Brasil
}

The monotypic Fuscous Flycatcher, Cnemotriccus fuscatus (Wied, 1831) (Tyrannidae), is widely distributed in South America eastern from the Andes, ranging from Venezuela, Guyana, and Colombia, southern to Ecuador, Peru, Bolivia, Paraguay, northeastern Argentina and most of Brazil, with seven diagnosable subspecies (Farnsworth and Lebbin, 2020). This is a common, but inconspicuous passerine which occurs in a variety of habitats, often close to water, including the undergrowth of dry and humid forests, gallery forests, and secondary woodlands, where they silently forage for insects (Belton, 1985; FFrench, 2012; de la Peña, 2016; Farnsworth and Lebbin, 2020). While nest and egg descriptions are available for different subspecies and/or localities (Ihering, 1900; Belton, 1985; Narosky and Salvador, 1998; Ffrench, 2012; Lopes et al. 2013; de la Peña, 2016), other reproductive aspects of $C$. fuscatus remain poorly documented.

Here we provide further reproductive data for $C$. f. bimaculatus (d'Orbigny \& Lafresnaye, 1837) from São Paulo state, southeastern Brazil. Specifically, we add knowledge to nest placement, egg characteristics, and nest material for $C$. $f$. bimaculatus, and we present for the first time incubation and nestling periods, nestling descriptions, as well as the first scientific photographic records of the eggs and nestlings for the whole species. Although our note is based on only one nest, it is justifiable in face of the total absence of information on these reproductive aspects.

We found the nest in 03 October 2019 in an area of arboreal Cerrado (Cerradão), only $2 \mathrm{~m}$ from the sharp transition with a gallery forest. The study site is located at the campus of São Carlos Federal University, in the city of São Carlos, state of São Paulo, southeastern Brazil $\left(21^{\circ} 58^{\prime} 37^{\prime \prime} \mathrm{S}, 47^{\circ} 52^{\prime} 18^{\prime \prime} \mathrm{W}\right.$ ) (for details on the study area, see Francisco, 2006). Nest measurements were obtained after fledging, using a caliper accurate to $0.1 \mathrm{~mm}$. Due to the evasive behavior of the parental individuals, eggs were photographed but not measured to avoid nest abandonment, and parental identification to the level of subspecies was achieved by obtaining an 86 min video with a GoPro Hero 5, that was placed approximately $1.5 \mathrm{~m}$ from the nest during incubation stage. Nestlings were photographed on a daily basis for development description. Incubation period was estimated from the day the last egg was laid to the day before the first egg hatched, and nestling period from the day of the first hatching to the day before fledging.

The nest was placed within a vertical cavity formed by a broken rotten trunk of an arboreal fern, $50 \mathrm{~cm}$ above ground. The trunk was densely covered by mosses and lichens, and the nest was partially hidden by the elongated leaves of a Cyperaceae (Figure 1a). The nest was a deep cup made of dry elongated leaves, lined with flexible stems and dark filaments (Figure 1a-g), measuring $65.4 \mathrm{~mm}$ in outer diameter, $47.6 \mathrm{~mm}$ in inner diameter, and $60 \mathrm{~mm}$ in depth. When found, the nest contained one egg, and two other eggs were laid during the following consecutive days (clutch size $=3$ eggs). Eggs were visually classified as "short oval" according to Winkler (2004), with pinkish background color, and sparse reddish-brown blotches and spots concentrated at the larger end (Figure 1b). Hatching was asynchronous, with only two of the three eggs hatching on two consecutive days. Incubation period estimated from the day the last egg was laid to the day before the first hatching was 14 days. One unhatched egg remained in the nest until fledging. Hatchlings (Figure 1c) had dark-red skin and were densely covered with dark-gray down. The beak was ochraceous at hatching and became dark-gray when nestling reached middle developmental stages, and swollen flanges were light-yellow (Figure 1c-g). One nestling disappeared in the $8^{\text {th }}$ day after hatching (Figure 1f), and the nestling period of the single young was 12 days (Figure 1g).

The types of reproductive information on C. fuscatus available in the literature and in the present work were summarized in Table 1 . Nest shape and nest material matched the previous description provided to a single nest of C. f. fuscatus (Wied, 1831) found in Rio Grande do Sul, southern Brazil (Belton, 1985), but differed from nests described for Tobago of C. f. cabanisi (Léotaud, 1866), that were made of twigs and bark (Ffrench, 2012), and from a nest of unspecified subspecies found in Minas Gerais state, southeastern Brazil, that had moss in the outer layer (Lopes et al. 2013). However, due to the limited number of described nests, we are unaware of whether these variations can represent the local availability of certain types of nest materials or variations between subspecies. Regarding to

*e-mail: dafiniletbruno@gmail.com

Received: June 28, 2021 - Accepted: September 30, 2021

This is an Open Access article distributed under the terms of the Creative Commons Attribution License, which permits unrestricted use, distribution, and reproduction in any medium, provided the original work is properly cited. 

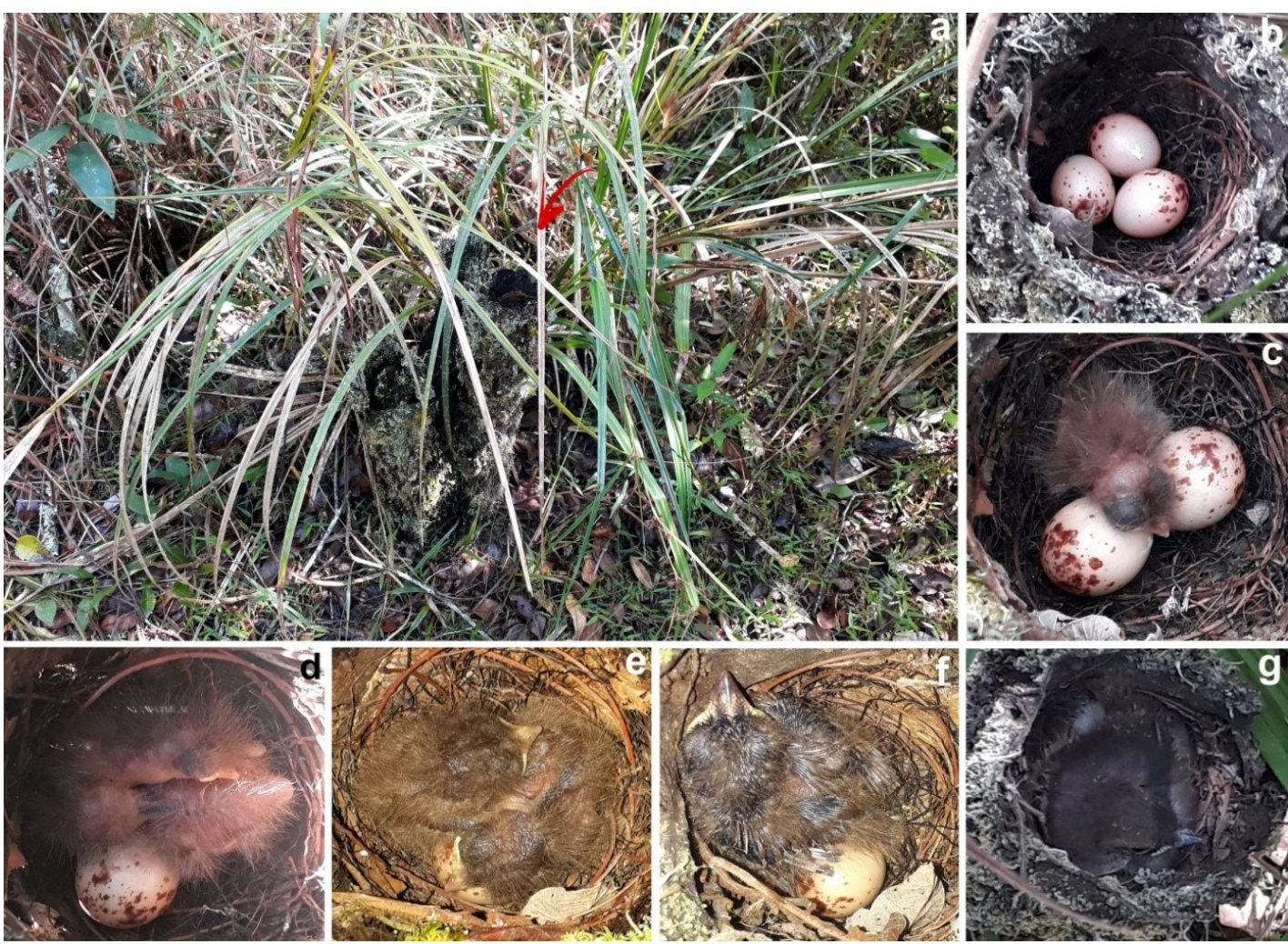

Figure 1. Nest site, nest, eggs and development stages of the Fuscous Flycatcher, Cnemotriccus fuscatus bimaculatus: (a) the arrow indicates the shallow horizontal cavity in which the nest was constructed, (b) closer view of the nest containing three eggs, (c) hatchling, (d) second day, (e) $4^{\text {th }}$ day, (f) $8^{\text {th }}$ day, and (g) $12^{\text {th }}$ day (the day before fledging).

Table 1. Summarization of the reproductive aspects of Cnemotriccus fuscatus reported in the literature and in the present work.

\begin{tabular}{|c|c|c|c|}
\hline Literature & Subspecies & Study site & Provided information \\
\hline Ihering (1900) & unspecified & Brazil & Eggs descriptions and measurements \\
\hline Belton (1985) & $\begin{array}{l}\text { C. f. fuscatus (Wied, } \\
\text { 1831) }\end{array}$ & Brazil - RS & $\begin{array}{l}\text { Nest shape, nest material, nest placement, nest } \\
\text { height, clutch size }\end{array}$ \\
\hline Belton (1985) & $\begin{array}{l}\text { C. f. bimaculatus } \\
\text { (d'Orbigny \& } \\
\text { Lafresnaye, } 1837 \text { ) }\end{array}$ & Brazil - RS & $\begin{array}{l}\text { Nest material, nest placement, nest height, clutch } \\
\text { size }\end{array}$ \\
\hline $\begin{array}{l}\text { Narosky and } \\
\text { Salvador (1998) }\end{array}$ & unspecified & Argentina & Eggs descriptions and measurement, clutch size \\
\hline Ffrench (2012) & $\begin{array}{l}\text { C. f. cabanisi (Léotaud, } \\
\text { 1866) }\end{array}$ & Tobago & $\begin{array}{l}\text { Eggs descriptions, nest material, nest placement, } \\
\text { nest height, clutch size }\end{array}$ \\
\hline Lopes et al (2013) & unspecified & Brazil - MG & $\begin{array}{l}\text { Eggs descriptions and measurements, nest material, } \\
\text { nest placement, nest height, nest measurements, } \\
\text { clutch size }\end{array}$ \\
\hline de La Peña (2016) & unspecified & Argentina & Eggs descriptions and measurement, clutch size \\
\hline $\begin{array}{l}\text { Additional data of } \\
\text { the present work }\end{array}$ & $\begin{array}{l}\text { C. f. bimaculatus } \\
\text { (d'Orbigny \& } \\
\text { Lafresnaye, 1837) }\end{array}$ & Brazil - SP & $\begin{array}{l}\text { Eggs descriptions, nest materials, nest placement, } \\
\text { nest measurements, clutch size, nestlings } \\
\text { descriptions, incubation and nestling periods and } \\
\text { first scientific photografic records }\end{array}$ \\
\hline
\end{tabular}

nest placement, the nest we found was similar to one nest of C. f. bimaculatus found in Rio Grande do Sul, which was within a rotted tree crevice, $40 \mathrm{~cm}$ above ground (Belton,
1985), and to one of the nests found in Minas Gerais state, that was within a cavity created by the fall of a decaying branch, $30 \mathrm{~cm}$ above ground (Lopes et al. 2013). Nests of $C$. 
f. cabanisi found in Tobago were constructed in tree crotches about $4 \mathrm{~m}$ above ground (Ffrench, 2012); two nests of $C$. f. fuscatus found in Rio Grande do Sul were sit between bromeliad leaves and the tree trunk, about $10 \mathrm{~m}$ above ground (Belton, 1985), and one of the two nests from Minas Gerais was in a ravine $1.8 \mathrm{~m}$ above ground (Lopes et al. 2013), evidencing that nests are basally supported, but nest placement can be variable. Citizen science images (wikiaves. com.br) permitted to confirm nest placement variations, with nests sit in rocks (WA4148472; Paula (2020)) and ravine depressions (WA4049393; Linhares (2015) and WA2845256; Adams (2017)). Eggs from Argentina (of unspecified subspecies) were described as creamy, with reddish and dark blotches (Narosky and Salvador 1998; de la Peña, 2016); those reported for Tobago (likely $C$. f. cabanisi) were described as white with black markings at the larger end (Ffrench, 2012); eggs of C.f. fuscatus were described as yellowish-white with purple isolated spots (Ihering, 1900), and those reported for Minas Gerais were creamy-salmon with a crown of rust stains around the large pole (Lopes et al. 2013). Although these descriptions are variable, overall, the eggs we found matched the previous findings, except for those from Tobago, which color seemed to be remarkably different. We could observe inconsistencies in the egg measurements present in the literature. One egg of C. f. fuscatus measured 20.5 x $16.0 \mathrm{~mm}$ (Ihering, 1900), and five eggs described for Argentina varied from 18.3 - $23.2 \mathrm{~mm}$ in length, and 13.6 - $16.0 \mathrm{~mm}$ in width (Narosky and Salvador, 1998; de la Peña, 2016), while six eggs from two nests found in Minas Gerais ranged from $16.4-17.6 \mathrm{~mm}$ in length, and $13.2-13.8 \mathrm{~mm}$ in width (Lopes et al. 2013). As the work of Lopes et al. (2013) was the only reporting the use of metal calipers to measure the eggs, these are likely the only reliable data. Clutch sizes were also three eggs for the nests found in Tobago ( $\mathrm{n}=3$ nests) (Ffrench, 2012) and in Minas Gerais state ( $\mathrm{n}=2$ nests) (Lopes et al. 2013), while two nests found in southern Brazil contained only one well-develop young each (Belton, 1985), matching our observation that only one nestling fledged. Breeding activities were recorded on November in southeastern and southern Brazil (Belton, 1985; Lopes et al. 2013), which together with our nest found in October, is within the breeding season range expected for most passerine birds from these regions (Belton, 1985; Marini and Durães, 2001). Following the pattern of other widely distributed taxa, breeding season in northern South America was remarkably different (see also Davanço et al. 2013; Perrella et al. 2017; Nunes et al. 2020), with nesting activities being recorded in February, April, May, and June in Tobago (Ffrench, 2012), although the number of studied nests is still not sufficient for precise breeding phenology determination.

Phylogenetic analyses have revealed a close relationship between Cnemotriccus Hellmayr, 1927 and Lathrotriccus Lanyon, W \& Lanyon, S, 1986 (Cicero and Johnson, 2002; Rheindt et al. 2008; Ohlson et al. 2008), and our data confirmed that eggs shape, patterns of egg markings, clutch sizes, and nest placement were similar between these taxa (see Aguilar et al. 1999; Greeney, 2014). Like in Cnemotriccus, nests of L. griseipectus (Lawrence, 1869) were also found in shallow tree hollows and in depressions created by bromeliad leaves (Greeney, 2014), and $L$. euleri (Cabanis, 1868) used shallow tree hollows more frequently, but also constructed nests in depressions on ravines (Aguilar et al. 1999). On the other hand, nests of Lathrotriccus had more substantial bases, and incubation and nestling periods were longer in this genus, being 16 and 14 days in one nest of $L$. griseipectus, and they averaged 17 and 15 days, respectively, in L. euleri (Aguilar et al. 1999; Greeney, 2014). Comparisons using the images presented for L. griseipectus (Greeney, 2014), permitted to note that the hatchlings of $C$. fuscatus had darker skins and had their bodies more densely covered by downs. The lack of basic reproductive information even for widely distributed taxa is not uncommon for Neotropical birds, and here we present some of the breeding aspects of $C$. fuscatus for the first time, which will contribute to future interpretations about the diversification of Neotropical flycatcher's breeding habits.

\section{Acknowledgements}

We are grateful to Secretaria Geral de Gestão Ambiental e Sustentabilidade(SGAS/UFSCar) for authorizing field work at the campus, and to Dr. Luís Fábio Silveira for contributing with the subspecies identification. Field work procedures were in compliance with the Brazilian legislation, being approved by Sisbio/MMA (Proc. \#66157-4) and by the Ethic Committee on Animal Use of the Federal University of São Carlos (CEUA/UFSCAR) (Proc. \#1405291118). DLB received a fellowship from Conselho Nacional de Desenvolvimento Científico e Tecnológico - CNPq (Proc\#131897/2019-5) and MRF receives a productivity research fellowship (Proc\# 308702/2019-0). We are also especially grateful to an anonymous referee for the important comments provided in the early versions of this manuscript.

\section{References}

ADAMS, G.B., 2017 [viewed 20 September 2021]. WA2845256, Cnemotriccus fuscatus (Wied, 1831) [online]. Wiki Aves - A Enciclopédia das Aves do Brasil. Available from: http://www. wikiaves.com/2845256

AGUILAR, T.M., LEITE, L.O. and MARINI, M.A., 1999. Biologia da nidificação de Lathrotriccus euleri (Cabanis, 1968) (Tyrannidae) em fragmentos de mata de Minas Gerais. Ararajuba, vol. 7, no. 2, pp. 125-133.

BELTON, W., 1985. Birds of Rio Grande do Sul, Brazil. Part 2: Formicariidae through Corvidae. Bulletin of the American Museum of Natural History, vol. 180, pp. 242p.

CICERO, C. and JOHNSON, N.K., 2002. Phylogeny and character evolution in the Empidonax group of Tyrant Flycatchers (Aves: Tyrannidae): a test of W.E. Lanyon's Hypothesis using mtDNA sequences. Molecular Phylogenetics and Evolution, vol. 22, no. 2, pp. 289-302. http://dx.doi.org/10.1006/mpev.2001.1054. PMid:11820849.

DAVANÇO, P.V., OLIVEIRA, L.S., SOUSA, L.M.S. and FRANCISCO, M.R., 2013. Breeding life-history traits of the Pale-breasted Thrush (Turdus leucomelas) in southeastern Brazil. Ornitologia Neotropical, vol. 24, pp. 401-411. 
DE LA PEÑA, M.R., 2016. Aves argentinas: descripción, comportamiento, reproducción y distribución. Tyrannidae a Turdidae. Argentina: Museo Provincial de Ciencias Naturales Florentino Ameghino, vol. 2, no. 1, 633 p.

FARNSWORTH, A. and LEBBIN, D.J., 2020. Fuscous Flycatcher (Cnemotriccus fuscatus). In: J. DEL HOYO, A. ELLIOTT, J. SARGATA, D. A. CHRISTIE, E. DE JUANA, eds. Birds of the World Alive. Ithaca, NY, USA: Cornell Lab of Ornithology. http://dx.doi.org/10.2173/ bow.fusfly 1.01

FFRENCH, R., 2012. A guide to the birds of Trinidad and Tobago. 3rd ed. New York: Cornell University Press, 436 p.

FRANCISCO, M.R., 2006. Breeding biology of the Double-collared Seedeater (Sporophila caerulescens). The Wilson Journal of Ornithology, vol. 118, no. 1, pp. 85-90. http://dx.doi. org/10.1676/1559-4491(2006)118[0085:BBOTDS]2.0.CO;2.

GREENEY, H., 2014. Breeding biology of the Grey-breasted Flycatcher Lathrotriccus griseipectus in south-west Ecuador. Bulletin of the British Ornithologists' Club, vol. 134, no. 1, pp. 14-18.

IHERING, H., 1900. Catálogo crítico-comparativo dos ninhos e ovos das aves do Brasil. São Paulo: Revista do Museu Paulista, 646 p.

LINHARES, S.F., 2015 [viewed 20 September 2021]. WA4049393, Cnemotriccus fuscatus (Wied, 1831) [online]. Wiki Aves - A Enciclopédia das Aves do Brasil. Available from: http://www. wikiaves.com/4049393

LOPES, L.E., PEIXOTO, H.J.C. and HOFFMANN, D., 2013. Notas sobre a biologia reprodutiva de aves brasileiras. Atualidades Ornitológicas, no. 171, pp. 33-49.

MARINI, M.A. and DURÃES, R., 2001. Annual patterns of molt and reproductive activity of passerines in South-Central Brazil. The Condor, vol. 103, no. 4, pp. 767-775. http://dx.doi.org/10.1093/ condor/103.4.767.
NAROSKY, T. and SALVADOR, S., 1998. Nidification de las aves argentinas: Tyrannidae. Buenos Aires: Asociación Ornitológica del Plata, $132 \mathrm{p}$.

NUNES, V.L., DAVANÇO, P.V., OLIVEIRA, L.S., FREITAS, M.S. and FRANCISCO, M.R., 2020. Reproductive aspects of the Yellowbellied Elaenia, Elaenia flavogaster (Tryrannidae), in the state of São Paulo, Brazil. Ornithology Research, vol. 28, no. 4, pp. 209-215. http://dx.doi.org/10.1007/s43388-020-00030-1.

OHLSON, J., FJELDSA, J. and ERICSON, G.P., 2008. Tyrant flycatchers coming out in the open: phylogeny and ecological radiation of Tyrannidae (Aves, Passeriformes). Zoologica Scripta, vol. 37, no. 3, pp. 315-335. http://dx.doi.org/10.1111/j.14636409.2008.00325.x.

PAULA, D.C., 2020 [viewed 20 September 2021]. WA4148472, Cnemotriccus fuscatus (Wied, 1831) [online]. Wiki Aves - A Enciclopédia das Aves do Brasil. Available from: http://www. wikiaves.com/4148472

PERRELLA, D.F., DAVANÇO, P.V., OLIVEIRA, L.S., SOUSA, L.M.S. and FRANCISCO, M.R., 2017. Reproductive aspects of the Purplethroated Euphonia, Euphonia chlorotica (Aves: Fringillidae) in southeastern Brazil, and first record of the species nesting inside a vespiary. Zoologia, vol.34, pp. 1-7. http://dx.doi.org/10.3897/ zoologia.34.e19989.

RHEINDT, F.E., NORMAN, J.A. and CHRISTIDIS, L., 2008. Phylogenetic relationships of tyrant-flycatchers (Aves: Tyrannidae), with an emphasis on the Elaeniine assemblage. Molecular Phylogenetics and Evolution, vol. 46, no. 1, pp. 88-101. http:// dx.doi.org/10.1016/j.ympev.2007.09.011. PMid:18042406.

WINKLER, D.W., 2004. Nests, eggs, and young: the breeding biology of birds. In: S. PODULKA, R.W. ROHRBAUGH JR and R. BONNEY, eds. Handbook of bird biology. 2nd ed. Ithaca: Cornell Lab of Ornithology, pp. 8.1-8.152. 